\title{
ADJUSTMENT TO ALDOSTERONE OR DESOXYCORTICOSTERONE ACETATE INDUCED SODIUM RETENTION IN PATIENTS WITH ADDISON'S DISEASE*
}

\author{
By J. THOMAS AUGUST $\dagger$ AND DON H. NELSON $\ddagger$ \\ (From the Department of Medicine, Peter Bent Brigham Hospital, the Harvard Medical School, \\ and the Howard Hughes Medical Institute, Boston, Mass.)
}

(Submitted for publication June 4, 1959; accepted July 17, 1959)

Long term administration of aldosterone (1) or desoxycorticosterone acetate (DCA) (2) to normal subjects has been shown, in certain instances, to produce continued renal potassium loss but only transient sodium and chloride retention. This adjustment of the renal response to sodium-retaining adrenal steroids has been termed an "escape" (3) from the expected effects of these compounds, and is seen clinically in the absence of edema with primary aldosteronism. The mechanism of this "escape" from sodium retention, that occurs despite continued excess of steroid sodium-retaining substances, is unknown. Some findings have suggested that the adrenal gland may play a role by producing a substance which either promotes sodium excretion or inhibits the sodium-retaining effect of other hormones.

An adrenal cortical "salt-losing hormone" was postulated by Wilkins and Lewis (4) and Jailer (5) to explain renal salt loss in cases of congenital adrenal hyperplasia. Rosemberg (6) suggested that this might be explained by an aldosterone-inhibiting effect of certain 21-desoxypregnane steroids, and Klein and co-workers (7) reported that partially purified material from urine of patients with congenital adrenal hyperplasia caused increased urinary sodium excretion in rats. Recently, Neher, Meystre and Wettstein (8) reported the isolation of $3 \alpha, 16 \alpha$-dihydroxy-pregnan20-one from patients with the adrenogenital saltlosing syndrome and demonstrated a salt-losing potential of this steroid in adrenalectomized rats. Increased renal sodium excretion has been re-

* Supported in part by grants from the John A. Hartford Foundation, Inc., New York, N. Y., and the United States Public Health Service, Bethesda, Md.

$\dagger$ Research Fellow in Medicine, Harvard Medical School; Assistant in Medicine, Peter Bent Brigham Hospital; American Heart Association Research Fellow.

$\$$ Associate in Medicine, Harvard Medical School; Associate in Medicine, Peter Bent Brigham Hospital. lated to several other steroid compounds as well. Thorn and co-workers (9) reported that patients with Addison's disease who conserved sodium, while receiving $5 \mathrm{mg}$. of DCA per day, showed an immediate increase in sodium excretion when 100 mg. of cortisone acetate per day was added. Progesterone has been shown by Landau and associates $(10,11)$ to result in natriuresis in normal subjects and treated patients with Addison's disease, and by Kagawa (12) to block the sodiumretaining effect of DCA in rats. Johnson (13) and Axelrod, Cates, Johnson and Luetscher (14) found that certain 11-oxycorticosteroids and 11desoxycorticosteroids produced increased sodium excretion in water-loaded, adrenalectomized rats. A synthetic steroid-17-spirolactone, 3-(3-oxo-17 $\beta$ hydroxy-4-androsten-17 $\left.\alpha-\gamma^{1}\right)$-propionic acid $\alpha$ lactone, and its 19-"nor" analog, counteract the sodium-retaining properties of DCA and aldosterone, possibly as a competitive inhibitor (15, 16). Neher and co-workers (17) have isolated another compound, $3 \beta, 16 \alpha$-dihydroxy-allopregnan20-one, from hog adrenals which, under certain biological conditions, also acts as a sodium-excreting factor.

Additional interest in the role of the adrenal gland in the "escape" was stimulated by the reports of severe edema in some patients with Addison's disease treated solely with DCA (18-23), in contrast to the response of normal subjects (1, 2). Also, in canine studies, Kovach and associates (24) reported that adrenalectomy prevented an expected increase in sodium excretion following intracarotid injection of hypertonic sodium chloride.

In the light of these observations, the following study of the "escape" mechanism in patients with Addison's disease given large amounts of aldosterone or DCA was undertaken. The data indicate that an adjustment to aldosterone or DCA 
induced sodium retention may occur in the absence of normal adrenal function.

\section{MATERIAL AND METHODS}

The five subjects of this study were three patients with Addison's disease of unknown etiology and two who had been completely adrenalectomized because of Cushing's syndrome with bilateral adrenal hyperplasia. The diagnosis of Addison's disease had been established clinically by low excretion of 17-ketosteroids (25) and 17-hydroxycorticosteroids (26), and by the absence of increased excretion of these steroids during administration of 25 units of adrenocorticotropic hormone (ACTH) intravenously over eight hours for two or three consecutive days. All had been maintained in good health with both cortisone and DCA or fluorohydrocortisone maintenance therapy, and were hospitalized on the Metabolic Ward for purposes of this study.

The subjects were given constant diets throughout the study. Body weight was determined under standard conditions at the beginning of each metabolic day. Urine was collected and stored at $5^{\circ} \mathrm{C}$. Measurements were made of sodium and potassium by flame photometry with an internal standard and of creatinine by the Jaffé reaction following precipitation with Lloyd's reagent.

The aldosterone used in this study was synthetic $d, l$-aldosterone-21-monoacetate which has approximately 50 per cent of the activity of the natural product (kindly provided by Drs. Robert Gaunt and C. H. Sullivan, Ciba Pharmaceutical Products, Inc., Summit, N. J.). The authenticity of this material was tested by paper chromatography before and after enzymatic hydrolysis. Recovery of steroid with the characteristics of aldosterone was consistent with a pure compound with the exception that a small amount of the aldosterone was initially not acetylated. It was administered intramuscularly in sesame oil in divided doses at eight hour intervals. DCA was administered intramuscularly every 12 hours. Vasopressin (Pitressin $(8)$ was given to one patient subcutaneously in aqueous suspension every eight hours.

Although endogenous adrenal corticosteroid secretions were not a factor in these studies, cortisone given as maintenance therapy could not be completely eliminated. The studies were designed with variations in cortisone dosage to eliminate its importance to a degree compatible with the health of the subjects.

\section{PROCEDURE AND RESULTS}

\section{Study I: Aldosterone with continued cortisone therapy (Figure 1, Table I)}

W.D., a 64 year old male, was given $3 \mathrm{mg}$. of $d, l$-aldosterone monoacetate while being maintained with $50 \mathrm{mg}$. of cortisone daily. Sodium intake was $174 \mathrm{mEq}$., chloride, $182 \mathrm{mEq}$. and potassium,

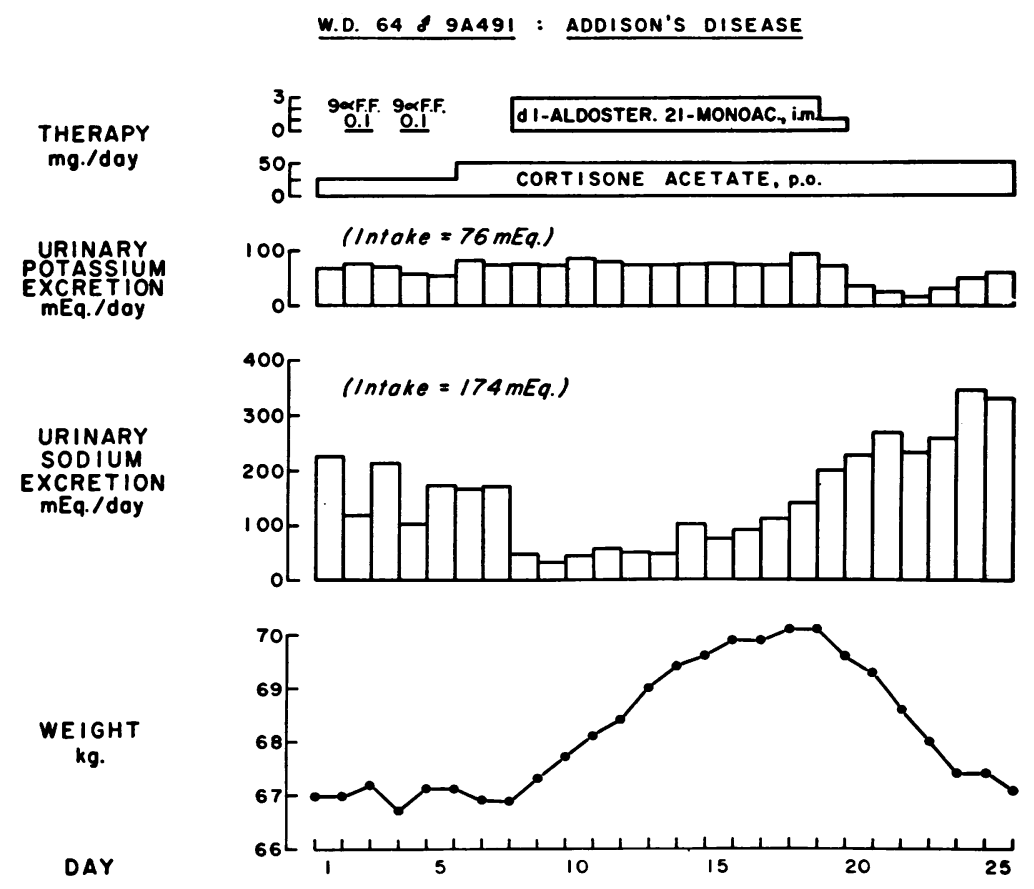

Fig. 1. Aldosterone With Continued Cortisone Therapy

The "escape" from renal sodium excretion began on the seventh day of aldosterone administration. 
TABLE I

Metabolic data on Subject W.D.

\begin{tabular}{|c|c|c|c|c|c|c|c|c|c|c|c|c|c|}
\hline \multirow[b]{2}{*}{ Day } & \multirow{2}{*}{$\begin{array}{l}\text { Body } \\
\text { wt. }\end{array}$} & \multicolumn{5}{|c|}{ Urine } & \multicolumn{3}{|c|}{ Blood } & \multirow{2}{*}{$\begin{array}{l}\text { Blood } \\
\text { pressure }\end{array}$} & \multicolumn{3}{|c|}{ Therapy } \\
\hline & & Volume & $\mathrm{Na}$ & $\mathbf{K}$ & $\mathrm{Cl}$ & Cer* & $\mathrm{Na}$ & $\mathbf{K}$ & $\mathrm{Cl}$ & & Cortisone & F.F.† & Aldosteroneł \\
\hline $\begin{array}{r}1 \\
2 \\
3 \\
4 \\
5 \\
6 \\
7 \\
8 \\
9 \\
10 \\
11 \\
12 \\
13 \\
14 \\
15 \\
16 \\
17 \\
18 \\
19 \\
20 \\
21 \\
22 \\
23 \\
24 \\
25\end{array}$ & $\begin{array}{l}K g . \\
67.0 \\
67.0 \\
67.2 \\
66.7 \\
67.1 \\
67.1 \\
66.9 \\
66.9 \\
67.3 \\
67.7 \\
68.1 \\
68.4 \\
69.0 \\
69.4 \\
69.6 \\
69.9 \\
69.9 \\
70.1 \\
70.1 \\
69.6 \\
69.3 \\
68.6 \\
68.0 \\
67.7 \\
67.4\end{array}$ & $\begin{array}{r}\text { ml./da. } \\
1,740 \\
1,220 \\
2,110 \\
1,250 \\
1,880 \\
1,400 \\
2,050 \\
960 \\
1,320 \\
1,420 \\
1,360 \\
800 \\
1,020 \\
1,820 \\
1,520 \\
1,160 \\
1,560 \\
2,030 \\
2,120 \\
2,140 \\
2,200 \\
1,680 \\
2,020 \\
1,900 \\
1,780\end{array}$ & $\begin{array}{r}226 \\
119 \\
213 \\
103 \\
171 \\
166 \\
172 \\
48 \\
32 \\
45 \\
58 \\
51 \\
47 \\
101 \\
75 \\
91 \\
111 \\
138 \\
200 \\
226 \\
268 \\
230 \\
259 \\
346 \\
332\end{array}$ & $\begin{array}{c}m E q . / d a \\
68 \\
78 \\
71 \\
57 \\
56 \\
82 \\
75 \\
76 \\
73 \\
86 \\
80 \\
75 \\
76 \\
76 \\
77 \\
75 \\
75 \\
114 \\
73 \\
37 \\
26 \\
18 \\
31 \\
47 \\
59\end{array}$ & $\begin{array}{r}207 \\
145 \\
222 \\
136 \\
188 \\
178 \\
178 \\
103 \\
79 \\
85 \\
106 \\
82 \\
97 \\
155 \\
132 \\
132 \\
164 \\
165 \\
205 \\
214 \\
260 \\
213 \\
240 \\
270 \\
297\end{array}$ & $\begin{array}{c}\text { ml./min. } \\
113 \\
128 \\
124 \\
\\
115 \\
140 \\
121 \\
133 \\
125 \\
136 \\
141 \\
132 \\
129 \\
149 \\
130 \\
127 \\
138 \\
136 \\
121 \\
127 \\
118 \\
125 \\
112\end{array}$ & $\begin{array}{l}146 \\
142 \\
145 \\
140 \\
138 \\
140 \\
141 \\
144 \\
146 \\
139 \\
135 \\
134 \\
137 \\
136 \\
143 \\
141 \\
148 \\
142 \\
142 \\
138 \\
138 \\
138\end{array}$ & $\begin{array}{c}m E q . / L . \\
4.5 \\
4.8 \\
4.3 \\
\\
4.1 \\
3.9 \\
4.1 \\
3.8 \\
4.0 \\
3.6 \\
3.9 \\
3.9 \\
3.9 \\
3.5 \\
3.8 \\
3.6 \\
3.7 \\
3.9 \\
3.6 \\
3.8 \\
4.1 \\
3.9 \\
3.5\end{array}$ & $\begin{array}{l}103 \\
111 \\
107 \\
107 \\
111 \\
108 \\
113 \\
111 \\
109 \\
107 \\
110 \\
109 \\
114 \\
111 \\
113 \\
113 \\
111 \\
109 \\
106 \\
101 \\
114 \\
108\end{array}$ & $\begin{array}{c}m m . \\
116 / 64 \\
120 / 70 \\
124 / 64 \\
120 / 74 \\
124 / 68 \\
122 / 72 \\
122 / 76 \\
118 / 62 \\
132 / 72 \\
140 / 76 \\
164 / 88 \\
160 / 88 \\
144 / 80 \\
148 / 80 \\
160 / 84 \\
164 / 90 \\
180 / 90 \\
168 / 80 \\
170 / 82 \\
160 / 76 \\
158 / 78 \\
148 / 82 \\
150 / 78 \\
154 / 76 \\
140 / 72\end{array}$ & $\begin{array}{l}25 \\
25 \\
25 \\
25 \\
25 \\
\mathbf{5 0} \\
\mathbf{5 0} \\
\mathbf{5 0} \\
\mathbf{5 0} \\
\mathbf{5 0} \\
\mathbf{5 0} \\
\mathbf{5 0} \\
\mathbf{5 0} \\
\mathbf{5 0} \\
\mathbf{5 0} \\
\mathbf{5 0} \\
\mathbf{5 0} \\
\mathbf{5 0} \\
\mathbf{5 0} \\
\mathbf{5 0} \\
\mathbf{5 0} \\
\mathbf{5 0} \\
\mathbf{5 0} \\
\mathbf{5 0} \\
\mathbf{5 0}\end{array}$ & $\begin{array}{c}\text { mg./da. } \\
0.1 \\
0.1\end{array}$ & $\begin{array}{l}3 \\
3 \\
3 \\
3 \\
3 \\
3 \\
3 \\
3 \\
3 \\
3 \\
1\end{array}$ \\
\hline
\end{tabular}

* Corrected to 1.73 M.2

$\dagger 9-\alpha$-Fluorohydrocortisone.

$\ddagger d, l$-Aldosterone-21-monoacetate.


Fig. 2. Cortisone Withdrawal After the "Escape" From DCA

Urinary sodium excretion was not significantly affected by doubling the amount of DCA administered or by gradual reduction of cortisone. 
$76 \mathrm{mEq}$. daily. Prior to the administration of aldosterone, sodium retention alternated with increased sodium excretion as the result of $0.1 \mathrm{mg}$. of 9- $\alpha$-fluorohydrocortisone given every other day. When aldosterone was administered, sodium excretion promptly diminished and remained between 32 and $58 \mathrm{mEq}$. per day for six days, accompanied by rapid weight gain. Chloride retention also occurred. Following a weight increase of $2.5 \mathrm{Kg}$., sodium chloride excretion gradually increased and the rate of weight gain diminished despite continued aldosterone administration. A moderate elevation of blood pressure persisted during the period of increased weight. After omission of aldosterone, there was potassium retention, increased sodium and chloride excretion and a loss of weight. There were no significant variations in endogenous creatinine clearance.
Study II: Cortisone withdrawal after "escape" from $D C A$ (Figure 2, Table II)

In this study, the mineralocorticoid was increased and the glucocorticoid decreased after the "escape" from sodium chloride retention had occurred. T.M., a bilaterally adrenalectomized male, 26 years of age, received $136 \mathrm{mEq}$. of sodium, 145 $\mathrm{mEq}$. of chloride and $138 \mathrm{mEq}$. of potassium daily. Maintenance hydrocortisone, $30 \mathrm{mg}$. daily, was given initially. During the first seven days of DCA administration, sodium excretion was 12 to $56 \mathrm{mEq}$. per day and there was a weight gain of $3.5 \mathrm{Kg}$. Thereafter, sodium excretion was as great as before DCA and there was no further consistent weight gain. The daily excretion of sodium following the "escape" was not significantly affected by doubling the amount of DCA

TABLE II

Metabolic data on Subject T.M.

\begin{tabular}{|c|c|c|c|c|c|c|c|c|c|c|c|c|}
\hline \multirow[b]{2}{*}{ Day } & \multirow{2}{*}{$\begin{array}{l}\text { Body } \\
\text { wt. }\end{array}$} & \multicolumn{5}{|c|}{ Urine } & \multicolumn{3}{|c|}{ Blood } & \multirow{2}{*}{$\begin{array}{c}\text { Blood } \\
\text { pressure }\end{array}$} & \multicolumn{2}{|c|}{ Therapy } \\
\hline & & Volume & $\mathrm{Na}$ & $\mathrm{K}$ & $\mathrm{Cl}$ & $\mathrm{C}_{\mathrm{er}} *$ & $\mathrm{Na}$ & $\mathrm{K}$ & $\mathrm{Cl}$ & & DCA & Cortisone \\
\hline & $K g$ & $m l . / d a$ & & $m E q . / d a$ & & $\operatorname{ml} . / \min$ & & $m E q . / L$ & & $m m$. & & $m g . / d a$. \\
\hline 1 & 61.7 & 1,850 & 121 & 110 & 134 & & & & & $122 / 80$ & & 30 \\
\hline 2 & 61.8 & 1,280 & 102 & 102 & 115 & 107 & 140 & 5.0 & 108 & $124 / 80$ & & 30 \\
\hline 3 & 61.7 & 2,000 & 118 & 102 & 126 & & & & & $120 / 80$ & & 30 \\
\hline 4 & 61.4 & 1,700 & 117 & 105 & 132 & 117 & 143 & 4.9 & 106 & $124 / 70$ & & 30 \\
\hline 5 & 61.4 & 1,330 & 83 & 87 & 106 & & & & & $118 / 80$ & & 30 \\
\hline 6 & 61.3 & 1,940 & 108 & 101 & 121 & 124 & 138 & 4.9 & 104 & $110 / 60$ & & 30 \\
\hline 7 & 60.3 & 1,540 & 96 & 99 & 115 & & & & & $120 / 72$ & & 30 \\
\hline 8 & 60.5 & 2,080 & 55 & 133 & 74 & & & & & $112 / 80$ & 15 & 30 \\
\hline 9 & 60.9 & 1,080 & 14 & 140 & 30 & 136 & 139 & 5.1 & 105 & $116 / 74$ & 15 & 30 \\
\hline 10 & 61.5 & 1,260 & 12 & 141 & 29 & & & & & $114 / 65$ & 15 & 30 \\
\hline 11 & 62.0 & 1,420 & 21 & 120 & 56 & 115 & 136 & 4.5 & 109 & $100 / 60$ & 15 & 30 \\
\hline 12 & 62.5 & 1,400 & 26 & 122 & 63 & & & & & $92 / 56$ & 15 & 30 \\
\hline 13 & 62.6 & 1,380 & 58 & 113 & 99 & 146 & 135 & 3.9 & 110 & $110 / 60$ & 15 & 30 \\
\hline 14 & 63.4 & 1,140 & 40 & 104 & 52 & & & & & $130 / 70$ & 15 & 30 \\
\hline 15 & 63.9 & 1,440 & 77 & 112 & 82 & 123 & 139 & 4.1 & 111 & $120 / 60$ & 15 & 30 \\
\hline 16 & 63.7 & 1,240 & 96 & 113 & 117 & & & & & $110 / 60$ & 15 & 30 \\
\hline 17 & 64.1 & 1,120 & 76 & 92 & 92 & & & & & $126 / 72$ & 15 & 30 \\
\hline 18 & 63.9 & 1,300 & 86 & 103 & 100 & 125 & 144 & 4.4 & 109 & $132 / 80$ & 15 & 30 \\
\hline 19 & 64.4 & 1,400 & 115 & 116 & 132 & & & & & $124 / 80$ & 15 & 30 \\
\hline 20 & 64.7 & 1,260 & 104 & 104 & 130 & 136 & 141 & 4.0 & 107 & $140 / 90$ & 15 & 30 \\
\hline 21 & 64.6 & 1,560 & 115 & 115 & 128 & & & & & $134 / 90$ & 15 & 30 \\
\hline 22 & 64.5 & 1,590 & 142 & 99 & 160 & 134 & 142 & 4.4 & 108 & $130 / 84$ & 15 & 30 \\
\hline 23 & 64.3 & 1,180 & 69 & 98 & 82 & & & & & $127 / 74$ & 15 & 30 \\
\hline 24 & 64.5 & 1,360 & 136 & 123 & 147 & & & & & $140 / 92$ & 30 & 30 \\
\hline 25 & 64.4 & 1,560 & 132 & 102 & 162 & 120 & 144 & 3.9 & 105 & $142 / 94$ & 30 & 30 \\
\hline 26 & 64.2 & 1,640 & 123 & 92 & 138 & & & & & $136 / 84$ & 30 & 30 \\
\hline 27 & 64.9 & 980 & 54 & 93 & 82 & 141 & 138 & 3.8 & 106 & $140 / 80$ & 30 & 20 \\
\hline 28 & 64.4 & 1,600 & 100 & 131 & 123 & 138 & 141 & 3.8 & 109 & $142 / 84$ & 30 & 10 \\
\hline 29 & 64.4 & 1,980 & 143 & 138 & 161 & 116 & 134 & 3.9 & 105 & $138 / 80$ & 30 & 5 \\
\hline 30 & 64.0 & 1,300 & 52 & 92 & 68 & 128 & 147 & 4.3 & 110 & $122 / 80$ & 30 & 2.5 \\
\hline 31 & 64.2 & 1,400 & 92 & 115 & 103 & & & & & $130 / 76$ & 30 & 2.5 \\
\hline 32 & 64.6 & 2,400 & 178 & 137 & 152 & & & & & $144 / 80$ & 30 & 2.5 \\
\hline 33 & 63.6 & 1,620 & 85 & 107 & 99 & 139 & 135 & 3.8 & 108 & $120 / 74$ & 30 & \\
\hline 34 & 64.0 & 1,460 & 93 & 111 & 117 & 124 & 139 & 3.6 & 108 & $132 / 68$ & 30 & \\
\hline
\end{tabular}

* Corrected to $1.73 \mathrm{M.}^{2}$. 
THERAPY

mg./doy

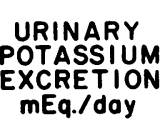
URINARY SODIUM
EXCRETION
mEq./doy
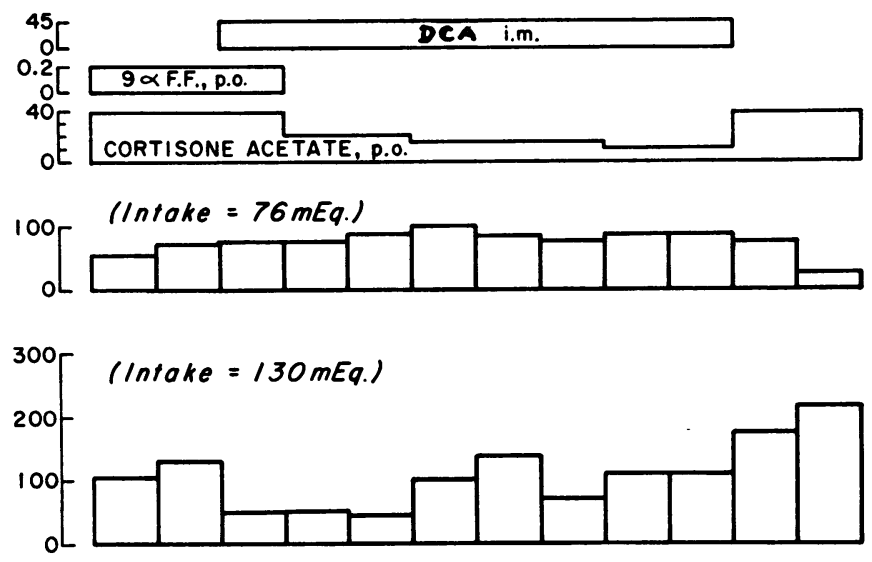

WEIGHT

kg.

DAY

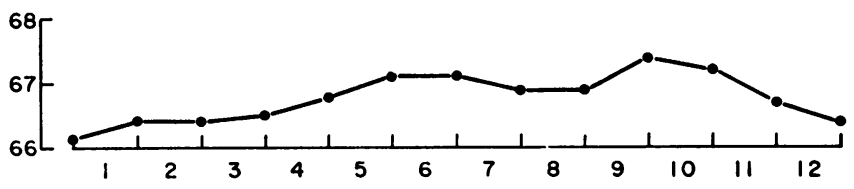

Fig. 3. Cortisone Withdrawal During "Escape" From DCA

administered to $30 \mathrm{mg}$. daily, by gradual reduction affected by the withdrawal of hydrocortisone. The of hydrocortisone, nor by total omission of hydrocortisone for one day. Endogenous creatinine observations could not be continued, however, due to a rapid decrease in the subject's sense of wellclearance and urine volume were not significantly being when hydrocortisone was withdrawn.

W.G. 42 \&6729: ADDISON'S DISEASE

THERAPY

mg./doy

URINARY

POTASSIUM

EXCRETION

$\mathrm{mEq}$ /day

URINARY

SODIUM

EXCRETION

mEq./doy

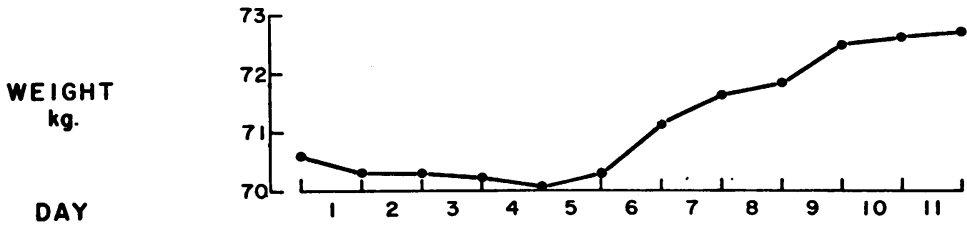

Fig. 4. DCA During Complete Cortisone Withdrawal

The "escape" was conclusive on the sixth and seventh day of DCA administration. 
Study III: Cortisone withdrawal during "escape" from $D C A$ (Figure 3)

Another bilaterally adrenalectomized male, age 30 , was given $45 \mathrm{mg}$. of DCA daily for nine days while cortisone was gradually diminished from 37.5 to $10 \mathrm{mg}$. daily. Sodium intake was 130 $\mathrm{mEq}$. and potassium, $76 \mathrm{mEq}$. daily. Sodium excretion fell to $49 \mathrm{mEq}$. on the first day of DCA given in conjunction with $0.2 \mathrm{mg}$. of $9-\alpha$-fluorohydrocortisone, the maintenance level of mineralocorticoid in this case. On the fourth and fifth days of DCA, when only $15 \mathrm{mg}$. of cortisone was being given, sodium excretion increased to 100 and $137 \mathrm{mEq}$. per day. Thereafter a cyclic pattern of sodium excretion, previously seen during the "escape," continued despite further reduction of the cortisone dosage to $10 \mathrm{mg}$. per day. It is noteworthy that the "escape" occurred in this case after a weight gain of only $0.7 \mathrm{Kg}$. as compared to a weight gain of 2.5 to $3.0 \mathrm{Kg}$., as seen in normal subjects (1) and the other patients in this study. A probable explanation for this finding is that excess body sodium and water were already present when DCA was first given, due to daily use of $0.2 \mathrm{mg}$. of $9-\alpha$-fluorohydrocortisone as maintenance therapy. This explanation is supported by other studies which showed that the sodium-retaining effects of $9-\alpha$-fluorohydrocortisone were inversely related to the initial exchangeable sodium in patients with Addison's disease (27). Moreover, it has been observed that patients with Addison's disease, who are depleted of salt and water, gain weight in excess of $3 \mathrm{Kg}$. before achieving sodium balance when given large amounts of DCA.

\section{Study IV:DCA during complete cortisone with- drawal (Figure 4)}

Cortisone was completely withdrawn while the patient with Addison's disease, age 42, was given $45 \mathrm{mg}$. of DCA daily. Previous maintenance therapy had been cortisone, $25 \mathrm{mg}$. and 9- $\alpha$-fluorohydrocortisone, $0.2 \mathrm{mg}$. daily. The diet in this study provided $200 \mathrm{mEq}$. of sodium and $116 \mathrm{mEq}$. of potassium per day. Sodium excretion was lowest, $62 \mathrm{mEq}$., on the third day of DCA administration and the "escape" was definite on the sixth day, after a weight gain of $2.3 \mathrm{Kg}$., when 142
A.R. 50 \&J7I3: ADDISON'S DISEASE
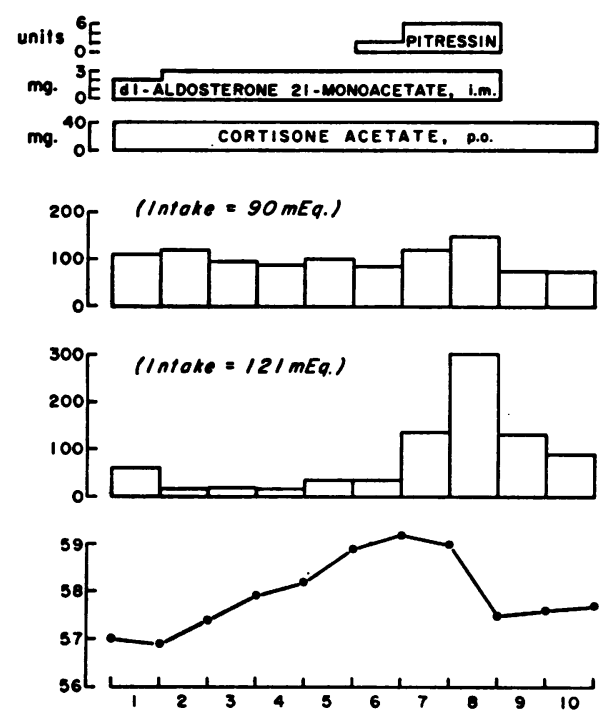

DAY

Fig. 5. Pitressin (B) During Aldosterone and CortiSONE Administration

Marked natriuresis and diuresis occurred when Pitres$\sin { }^{(17}$ was given after five days of aldosterone administration.

$\mathrm{mEq}$. of sodium was excreted. On the last day of DCA, $214 \mathrm{mEq}$. of sodium was excreted.

\section{Study $V$ : Pitressin ${ }^{\circledR}$ during aldosterone and corti- sone therapy (Figure 5)}

A 54 year old woman with Addison's disease, while receiving $40 \mathrm{mg}$. of cortisone and $3 \mathrm{mg}$. of $d, l$-aldosterone acetate daily, was given aqueous Pitressin ${ }^{\circledR}$. Sodium intake was $121 \mathrm{mEq}$. and potassium, $90 \mathrm{mEq}$. per day. Following a weight gain of $2 \mathrm{Kg}$., marked natriureses of 134 and 301 $\mathrm{mEq}$. and diuresis occurred on the second and third days of Pitressin ${ }^{\circledR}$ administration despite continued aldosterone. It may be noted that neither weight gain nor water retention was apparent during the 24 hour periods of Pitressin ${ }^{\circledR}$ administration.

\section{DISCUSSION}

It was previously shown, in normal subjects receiving 3 to $6 \mathrm{mg}$. of $d, l$-aldosterone-21-monoacetate daily, that sodium and water retention ceased following weight gain of approximately $3 \mathrm{Kg}$. (1). Since the responses of the patients with Addison's disease in this study appear similar to 
those seen in the normal subjects, it is unlikely that secretion of an adrenal cortical "sodiumexcreting" hormone is responsible for the return to sodium balance which occurs during continued administration of sodium-retaining steroid.

Whether the "escape" phenomenon would occur or continue in all patients with Addison's disease treated solely with aldosterone or DCA cannot be determined from this study. Diminution or withdrawal of glucocorticoid therapy in three of the studies did not indicate that the "escape" depends on cortisone but the period of withdrawal from cortisone was not prolonged. Reports describing treatment of patients with Addison's disease with DCA alone indicate that many gained not more than 2 to $4 \mathrm{Kg}$. and did not become severely edematous despite administration of up to $40 \mathrm{mg}$. of DCA daily combined with large sodium chloride intake (28-32). However, several cases of massive edema and congestive heart failure have been attributed to DCA therapy (18-23). The number of complicating factors which may have prevailed make the interpretation of these cases difficult. Pre-existing cardiac or renal disease may have been present in some $(19,21,23)$, and others were severely ill due to adrenal insufficiency. In this respect, it should be noted that continued sodium retention is not the normal response to a mineralocorticoid, and that patients with congestive heart failure, cirrhosis with ascites, or nephrosis, respond differently from normal subjects (33). These patients show virtually complete sodium retention, continuous weight gain without an "escape" and urinary potassium excretion not in excess of intake. Patients with preexisting abnormal sodium retention and edema, or patients with low cardiac or hepatic reserve with a tendency to edema formation, would not be expected to "escape" from the sodium-retaining effects of aldosterone or other mineralocorticoids. It may be possible that severe, untreated glucocorticoid deficiency would result in abnormal renal function and continued sodium chloride retention during treatment with a mineralocorticoid. This is not to say, however, that an adrenal hormone is directly responsible for the "escape" phenomenon.

\section{SUMMARY}

Five patients with Addison's disease, in two due to bilateral adrenalectomy, received large amounts of aldosterone or desoxycorticosterone acetate while on constant diets. Glucocorticoid therapy was varied in the different patients as follows. It was held constant, gradually reduced after the "escape" from sodium retention, gradually reduced before and during the "escape," and completely omitted. In one study, Pitressin ${ }^{\circledR}$ was given with aldosterone. In each of these patients with Addison's disease, sodium chloride retention was transient and apparently was not acutely affected by change in glucocorticoid therapy. It is concluded that an adrenal cortical "sodium-excreting" hormone is not responsible for the "escape" from sodium retention that occurs despite continued administration of sodiumretaining hormone.

\section{ACKNOWLEDGMENTS}

The authors are indebted to Dr. George W. Thorn for his advice and criticism of this project. We wish to thank the following for technical assistance: Miss Adelaide Foisie, Miss Ruth Mariner and Miss Cynthia Emerson.

\section{REFERENCES}

1. August, J. T., Nelson, D. H., and Thorn, G. W. Response of normal subjects to large amounts of aldosterone. J. clin. Invest. 1958, 37, 1549.

2. Relman, A. S., and Schwartz, W. B. The effect of DOCA on electrolyte balance in normal man and its relation to sodium chloride intake. Yale $\mathrm{J}$. Biol. Med. 1952, 24, 540.

3. Relman, A. S., Stewart, W. K., and Schwartz, W. B. A study of the adjustments to sodium- and waterretaining hormones in normal subjects (abstract). J. clin. Invest. 1958, 37, 924.

4. Wilkins, L., and Lewis, R. A. The renal excretion of steroid hormones in pseudohermaphroditism and male sexual precocity associated with symptoms of Addison's disease in Conference on Metabolic Aspects of Convalescence, Edward C. Reifenstein, Jr., Ed. New York, Josiah Macý, Jr. Foundation, 1948, p. 168.

5. Jailer, J. W., Evidence for a "salt-losing" adrenal hormone in congenital adrenal virilism associated with Addisonian-like symptoms (abstract). J. clin. Endocr. 1951, 11, 798.

6. Rosemberg, E. Inhibition of desoxycorticosterone (DOC) action in the bilaterally adrenalectomized rat by certain $\mathrm{C}_{2}$ steroids. The Endocrine Society, Program of the 39th Meeting. 1957, p. 68.

7. Klein, R., Taylor, P., Papadatos, C., Laron, Z., Keele, D., Fortunato, J., Byers, C., and Billings, C. Sodium losing material in human urine. Proc. Soc. exp. Biol. (N. Y.) 1958, 98, 863. 
8. Neher, R., Meystre, Ch., and Wettstein, A. Neue 16- $\alpha$-hydroxysteroide aus menschlichem Urin und aus Schweine-Nebennieren. Isolierung, Konstitution, Synthesen. Helv. chim. Acta 1959, 42, 132.

9. Thorn, G. W., Forsham, P. H., Bennett, L. L., Roche, M., Reiss, R. S., Slessor, A., Flink, E. B., and Somerville, W. Clinical and metabolic changes in Addison's disease following the administration of compound $\mathrm{E}$ acetate. Trans. Ass. Amer. Phycns 1949, 62, 233.

10. Landau, R. L., Bergenstal, D. M., Lugibihl, K., and Kascht, M. E. The metabolic effects of progesterone in man. J. clin. Endocr. 1955, 15, 1194.

11. Landau, R. L., Bergenstal, D. M., Lugibihl, K., Dimick, D. F., and Rashid, E. The relationship of estrogen and of pituitary hormones to the metabolic effects of progesterone. J. clin. Endocr. 1957, 17, 177.

12. Kagawa, C. M. Blocking urinary electrolyte effects of desoxycorticosterone with progesterone in rats. Proc. Soc. exp. Biol. (N. Y.) 1958, 99, 705.

13. Johnson, B. B. Bioassay of adrenal cortical steroids on the basis of electrolyte excretion by rats: Effects of 11-desoxy and 11-oxysteroids. Endocrinology 1954, 54, 196.

14. Axelrod, B. J., Cates, J. E., Johnson, B. B., and Luetscher, J. A., Jr. Bioassay of mineralocorticoids: Relationship of structure to physiological activity. Endocrinology 1954, 55, 568.

15. Kagawa, C. M., Cella, J. A., and Van Arman, C. G. Action of new steroids in blocking effects of aldosterone and deoxycorticosterone on salt. Science 1957, 126, 1015.

16. Liddle, G. W. Aldosterone antagonists. A. M. A. Arch. intern. Med. 1958, 102, 998.

17. Neher, R., Desaulles, P., Vischer, E., Wieland, P., and Wettstein, A. Isolierung, Konstitution und Synthese eines neuen Steroides aus Nebennieren. Helv. chim. Acta 1958, 41, 1667.

18. Ferrebee, J. W., Ragan, C., Atchley, D. W., and Loeb, R. F. Desoxycorticosterone esters. Certain effects in the treatment of Addison's Disease. J. Amer. med. Ass. 1939, 113, 1725.

19. Loeb, R. F., Atchley, D. W., Ferrebee, J. W., and Ragan, C. Observations on the effect of desoxycorticosterone esters and progesterone in patients with Addison's Disease. Trans. Ass. Amer. Phycns 1939, 54, 285.

20. Wilder, R. M. Progress in treatment of Addison's Disease. Proc. Mayo Clin. 1940, 15, 273.

21. Willson, D. M., Rynearson, E. H., and Dry, T. J. Cardiac failure following treatment of Addison's
Disease with desoxycorticosterone acetate. Proc. Mayo Clin. 1941, 16, 168.

22. Thorn, G. W., Dorrance, S. S., and Day, E. Addison's disease: Evaluation of synthetic desoxycorticosterone acetate therapy in 158 patients. Ann. intern. Med. 1942, 16, 1053.

23. Currens, J. H., and White, P. D. Congestive heart failure and electrocardiographic abnormalities resulting from excessive desoxycorticosterone acetate therapy in the treatment of Addison's disease. Amer. Heart. J. 1944, 28, 611.

24. Kovach, A. G. B., Földi, M., Papp, N., Roheim, P. S., and Koltay, E. Cerebral regulation of sodium excretion. Lancet 1959, 1, 338.

25. Drekter, I. J., Heisler, A., Scism, G. R., Stern, S., Pearson, S., and McGavack, T. H. The determination of urinary steroids. I. The preparation of pigment-free extracts and a simplified procedure for the estimation of total 17-ketosteroids. J. clin. Endocr. 1952, 12, 55.

26. Reddy, W. J. Modification of Reddy-Jenkins-Thorn method for estimation of 17-hydroxycorticosteroids in urine. Metabolism 1954, 3, 489.

27. Munro, D. S. The action of fluorocortisone and aldosterone on sodium and potassium metabolism in Addison's disease. Clin. Sci. 1958, 17, 205.

28. Thorn, G. W., Howard, R. P., and Emerson, K, Jr. Treatment of Addison's disease with desoxy-corticosterone acetate, a synthetic adrenal cortical hormone (preliminary report). J. clin. Invest. 1939, 18, 449.

29. Simpson, S. L., Wilkinson, J. F., Himsworth, H. P., Jones, A., and Dryerre, H. W. Discussion on recent developments in the treatment of Addison's disease. Proc. roy. Soc. Med. 1939, 32, 685.

30. Cleghorn, R. A., Fowler, J. L. A., and Wenzel, J. S. The treatment of Addison's disease by a synthetic adrenal cortical hormone (desoxycorticosterone acetate). Canad. med. Ass. J. 1939, 41, 226.

31. Tooke, T. B., Jr., Power, M. H., and Kepler, E. J. The tolerance of patients suffering from Addison's disease to potassium while such patients are being treated with desoxycorticosterone acetate. Proc. Mayo Clin. 1940, 15, 365.

32. McGavack, T. J. Optimal dosage and the reciprocal relation of desoxycorticosterone acetate and sodium in Addison's disease. New Engl. J. Med. 1942, 226, 547.

33. Nelson, D. H., and August, J. T. Abnormal response of edematous patients to aldosterone or desoxycorticosterone. Lancet. In press. 